\title{
17B-Estradiol Levels During An Entire Menstrual Cycle In Response To Adult Stature and Insulin, Of Possible Importance For Breast Cancer Risk: The EBBA-I study.
}

\section{Citation}

Espetvedt, Sissi, Aina Emaus, Steinar Tretli, Grazyna Jasienska, Peter T. Ellison, Anne-Sofie Furberg, Erik Wist, and Inger Thune. 2009. 17B-estradiol levels during an entire menstrual cycle in response to adult stature and insulin, of possible importance for breast cancer risk: The EBBA-I study. CTRC-AACR San Antonio Breast Cancer Symposium: 2008 Abstracts. Cancer Research 69(2)(Supplement): 273S-274S.

\section{Published Version}

http://dx.doi.org/10.1158/0008-5472.SABCS-4078

\section{Permanent link}

http://nrs.harvard.edu/urn-3:HUL.InstRepos:3008263

\section{Terms of Use}

This article was downloaded from Harvard University's DASH repository, and is made available under the terms and conditions applicable to Open Access Policy Articles, as set forth at http:// nrs.harvard.edu/urn-3:HUL.InstRepos:dash.current.terms-of-use\#OAP

\section{Share Your Story}

The Harvard community has made this article openly available.

Please share how this access benefits you. Submit a story.

\section{Accessibility}


$17 \beta$-estradiol levels during an entire menstrual cycle in response to adult stature and insulin, of possible importance for breast cancer risk. The EBBA-I study.

Sissi Espetvedt, Aina Emaus, Steinar Tretli, Grazyna Jasienska, Peter T. Ellison, AnneSofie Furberg, Erik Wist, Inger Thune

Abstract:

Background: The normal breast cells develop into malignant cells as a result of a complex interplay between genetic, environmental, nutritional and hormonal factors. Attained adult stature and insulin levels, risk factors for breast cancer, may also vary in response to the same factors. Thus, we hypothesize that $17 \beta$-estradiol, a key factor in the carcinogenesis of the breast, may vary in response to adult height in combination with insulin levels of possible importance of breast cancer risk.

Methods: Among 204 healthy women, aged 25-35 years who participated in the Norwegian EBBA-I study, 17ß-estradiol concentrations were measured in daily saliva samples throughout one entire menstrual cycle using radioimmunoassay (RIA). Attained height $(\mathrm{cm})$ was measured, and serum concentrations of insulin were determined in fasting blood samples. The associations between adult height, insulin and $17 \beta$-estradiol levels throughout a menstrual cycle were studied using multivariate linear regression analyses and linear mixed models for repeated measures. Adjustments for potential confounding factors were performed.

Results: A $37.2 \%$ increase in $17 \beta$-estradiol levels was observed during the entire menstrual cycle among women with an adult height $\geq 170 \mathrm{~cm}$ (upper tertile) and insulin levels $\geq 90 \mathrm{pmol} / \mathrm{L}$ (upper tertile) compared to women with the same attained adult height, and insulin levels $<90 \mathrm{pmol} / \mathrm{L}$. The association was even more pronounced when we looked into those women with attained adult height $\geq 170 \mathrm{~cm}$ (upper tertile) and serum insulin $\geq 101 \mathrm{pmol} / \mathrm{L}$ (upper quartile) (Fig. 1). Adjustments for potential confounding factors were performed.

Conclusion: Our findings support that premenopausal levels of $17 \beta$-estradiol vary in response to adult height and insulin levels, suggesting that women who become taller are put at risk for higher estradiol levels throughout the entire menstrual cycle when their insulin levels rise, of possible importance for breast cancer risk.

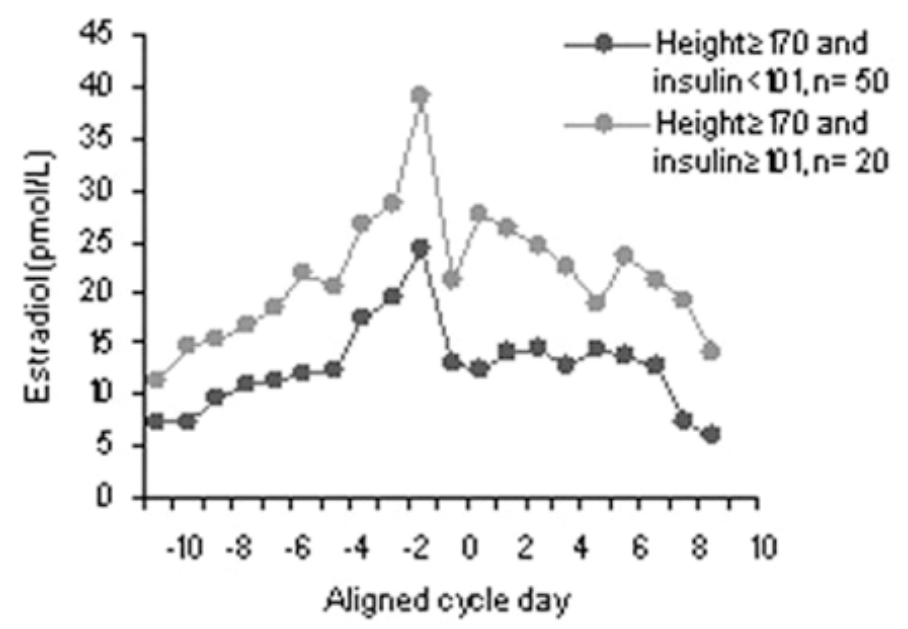

